\title{
PUBLICATIONS RELATING TO THE REACTIONS OF MEDICAL STUDENTS TO HUMAN CADAVERS AND ETHICS
}

\begin{abstract}
Mehmet Karatas ${ }^{1}$
Abstract: Objectives: Faculty of Medicine students are practicing on a human cadaver in the course of education especially in Anatomy lessons. There are some physical, emotional, and ethical problems that students have experienced with participation in these lessons. In some publications we have reviewed issues regarding these, we aimed to reveal whether ethical issues are being addressed. Methods: We conducted literature searches by writing the clues "Publications relating to the Faculty of Medicine student's reactions to cadavers lessons and ethics" on search engines on the internet. By examining the articles obtained, we investigated whether students are experiencing problems, especially on ethics. Results: 28 articles $(90.3 \%)$ were original research, $2(6.4 \%)$ were reviews and $1(3.2 \%)$ was a book. Only 6 out of these studies (19.3\%) have addressed ethical issues. In our research, quite a few publications $(19.3 \%)$ have been found that dealt with ethical problems in cadaver lessons. Human body dissection during an anatomy course for the first-year medical students raises questions about invasion of privacy, cadaver sources, dying, and death. Conclusion: Detailed reviews of the situations that causes ethical problems in the studies to be done in this direction are thought to be beneficial to the medical faculties students education.
\end{abstract}

Key words: Medical students, cadavers, reactions, ethics

Publicaciones relacionadas con las reacciones de los estudiantes médicos hacia cadáveres humanos y ética

Resumen: Objetivos: Los estudiantes de la Facultad de Medicina practican con cadáveres humanos, especialmente en lecciones de anatomía. Los estudiantes experimentan problemas emocionales, físicos y éticos al participar en estas lecciones. Después de revisar publicaciones que tratan este tema, nuestro objetivo es evaluar si se abordan los temas éticos. Métodos: Realizamos búsquedas en la literatura mediante motores de búsqueda en internet usando las palabras clave: "Publicaciones relacionadas con las reacciones de estudiantes de Facultad de Medicina a lecciones que usan cadáveres y ética”. Al examinar los artículos, investigamos si los estudiantes experimentaban problemas, especialmente de ética. Resultados: 28 artículos (90,3\%) eran investigaciones originales, 2 (6,4\%) eran revisiones y uno (3,2\%) un libro. Solamente 6 de estos estudios (19,3\%) abordaban temas éticos en relación con lecciones usando cadáveres. La disección del cuerpo humano en cursos de anatomía de estudiantes de medicina de primer ańo produce cuestionamientos sobre invasión de privacidad, origen de los cadáveres, el morir y la muerte. Conclusión: se considera que las revisiones detalladas de las situaciones que causan problemas éticos en los estudios que se realizan en esta dirección son beneficiosas para la educación de los estudiantes de facultades médicas.

Palabras clave: estudiantes de medicina, cadáveres, reacciones, ética

\section{Publicaçóes relacionadas com as reaçóes dos estudantes de medicina à cadáveres humanos e ética}

Resumo: Objetivos: Estudantes de medicina estão praticando ensinamentos em cadáveres humano no curso de graduação, especialmente nas aulas de anatomia. Existem algumas questôes físicas, emocionais e éticos que os estudantes têm experimentado ao participar em essas aulas. Em algumas publicaçóes, que nós analisamos estas questóes, tivemos como objetivo revelar se questôes éticas estavam sendo abordadas. Métodos: Nós conduzimos pesquisas de literatura, buscando em endereços eletrônico de busca por "Publicaçôes relativas à reaçôes de estudantes de medicina a experimentos com cadáveres e ética". Examinando os artigos obtidos, investigamos se os alunos estáo enfrentando problemas, especialmente com relaçáo a ética. Resultados: 28 artigos $(90,3 \%)$ eram pesquisas originais, $2(6,4 \%)$ foram resenhas e $1(3,2 \%)$ um livro. Somente 6 destes estudos $(19,3 \%)$ abordaram questóes éticas. Em nossa pesquisa, foram encontradas várias publicações (19,3\%) que tratam de problemas éticos nas liçóes de cadáver. Dissecação do corpo humano durante um curso de anatomia para estudantes de medicina do primeiro ano levanta questôes sobre invasão de privacidade, fontes de cadáver, morrer e morte. Conclusão: Revisões detalhadas das situaçóes que provoca problemas éticos nos estudos são considerados benéficos para o ensino de medicina.

Palavras-chave: estudantes de medicina, cadáveres, reações, ética

\footnotetext{
${ }^{1}$ Dept. of History of Medicine and Ethics, Faculty of Medicine, Inonu University. Malatya, Turkey Correspondence: drkaratas@hotmail.com
} 


\section{Introduction}

In the past, anatomization of convicted person's body was sometimes ordered as part of their punishment. The bodies were taken to a local slaughterhouse, dismembered and their remains were denied a burial as a symbol of insult(1).

The earliest science-oriented systematic human dissections were carried out by the Greeks in the early part of the third century BC. In the $13^{\text {th }}$ century, Europe dissection and autopsy of humans was regularly carried out with reasonable sociocultural and religious acceptance(1).

The dissection of human cadavers for medical education has experienced various cycles of legalization and prohibition in different countries. But no universal prohibition of dissection or autopsy was exercised during the middle ages. The ways to obtain a body from "front doors" were full of legal hurdles and prompting many institutions to consort to unethical means, because the only bodies legally available were those of executed criminals which were scant to meet the rising educational demands(1).

Anatomy is the basis of medical and health professional education. Dissection enables the human cadavers organs to be examined systematically and topographically. In the anatomy laboratory, students are confronted with the body of a person who has voluntarily, in most cases, surrendered himself or herself to the medical profession to be palpated, probed, cut, explored, discussed, and evaluated(2-4).

First-year medical students start and/or enter the course by going through the anatomy curriculum, which involves interaction with cadavers and cadaveric material(5).

One of the sensitivities that students should have in these courses is ethics. Ethics is about the behaviors that people make at the social scale and which have consequences that affect others and the thinking processes that shape them. As a subfield of philosophy, it deals with what ethics is, what goodness means in terms of behavior and what is good; aims to formulate the ideal behavior of the human being(6-8).
The ethical values are those criteria for thinking processes which determine behavior in the mind and provide a source of rules governing behavior at the community level. Ethical rules are those that are more concrete than ethical principles and are derived from ethical principles, which guide behaviors such as ethical principles(6-8).

The principles of beneficence, nonmaleficence, justice, and autonomy, which are accepted as international ethical principles. The greatest damage that may occur while providing health care is the death of the patient. The medical faculty students are trained to be a benefit to their patients during medical education. In this process, it is also in the direction of "primum non nocere" (non-maleficence) principle which is included in Hippocratic teachings to provide health services without deteriorating the current situation of the patients. Especially, beneficence and nonmaleficence ethical principles have complementary processes. Anyone who is willing to benefit from health services under the justice principle shall be entitled to any ethnic origin, material status, gender, nationality, country, religion, profession, it is necessary to ensure that all patients are available without any discrimination. Autonomy requires that patients be included in the decision-making process by adding them to their diagnosis and treatment processes(9).

According to this, each individual should have autonomous control over the disposition of his or her body after death. The emphasis here is on what an individual decrees should or should not be done with his or her body at death, despite social need or public interest. This is a principle that has been overlooked far more frequently than it has been followed. It was ignored until the 1950s or 1960s at the earliest, and it continued to be ignored in many societies where bodies for dissection and organs for donation are scarce. The use of unclaimed bodies has become so much an integral part of the anatomical ethos provided by the autonomy principle, as an ethical dimension have been generally ignored(10).

In particular, ethical principles need to be based on the principle of autonomy, that people have rights in their lives, and in decisions to be made about themselves after they die. It is useful to say 
that the relatives of the people in this issue also have a say. The acquisition of cadavers is not only for the cadaveric donation of one's life in life but also for the unfounded cadavers.

It is obvious that the process of acquisition is very difficult, especially in the education processes of the cadavers, in particular for the medical faculty students. What is so important is that cadavers and students' confrontations can cause physical, emotional and ethical problems. With this study, we tried to reveal whether the students of medical faculties have experienced ethical problems in cadaver lessons by researching the publications that have previously been made on the topic.

\section{Methods}

We conducted a literature search by writing the "Publications relating to the Faculty of Medicine students reactions to cadavers lessons and ethics" on search engines on the internet on December 26, 2017.

Since the search engines provided information that can change at any time, we took the output of the pages we found and made them based on the headlines we found to work.

There were 23 results in search engine. The results were searched one by one to try to reach all the related articles under them. A total of 28 research articles, 2 reviews and 1 book relating to the subject were identified. Non-relevant and unattainable topics were excluded from the study.

The obtained articles were researched in terms of the problems that medical faculty students lived with during cadaver lessons. By researching these articles, we investigated whether students were experiencing problems, especially on ethics.

We searched for the following headings that may have ethical problems in the articles:

- Lack of approval for being a cadaver in life,

- Being a student who thinks that a cadaver is a human being and should not be touched to harm it,

- The presence of a student in the opposite sex who does not want to examine her due to the gender of the cadaver,

- The student's rejection of this course,

- Trying to make a selfie with a cadaver,

- Have fun with a cadaver,

- Damage to the cadaver unnecessarily,

- Forgetting that once the cadaver was a human being, disrespectful behaviors are exhibited by students and educators.

In addition, in these publications, contents that might be relating to ethics, such as ethical issues, ethical problems, were also scanned.

\section{Results}

28 articles (90.3\%) were original research, 2 (6.4\%) were reviews and 1 (3.2\%) was a book. Only 6 out of these studies (19.3\%) have addressed ethical issues, 4 (12.9\%) of the original researches mentioned the general ethical problem in cadaver lessons. In the book, cadaver studies have been evaluated in terms of ethics. The necessity of cadaver courses was only discussed in one of the reviewed publications and a general approach to the ethical problem in these lessons have been demonstrated (Table 1).

Table 1: Publications we have investigated and studies involving ethical evaluation.

\begin{tabular}{|c|c|c|}
\hline & $\begin{array}{c}\text { Publications } \\
\text { we have } \\
\text { investigated }\end{array}$ & $\begin{array}{c}\text { Involving } \\
\text { ethical } \\
\text { evaluation }\end{array}$ \\
\hline & $\mathrm{n} / \%$ & $\mathrm{n} / \%$ \\
\hline $\begin{array}{c}\text { Original } \\
\text { Article }\end{array}$ & $28(90.3)$ & $4(12.9)$ \\
\hline Review Article & $2(6.4)$ & $1(3.2)$ \\
\hline Book & $1(3.2)$ & $1(3.2)$ \\
\hline Total & $31(100)$ & $6(19.3)$ \\
\hline
\end{tabular}




\section{The findings of 4 researches, 1 review and 1 book on ethical issues}

In Agnihotri and Sagoo's questionnaire, which questioned the acceptability of cadaveric dissection as a question, it was determined that this question was $19.66 \%$ yes, $66.66 \%$ no, $13.66 \%$ unanswered(11).

In the Rajeh et al research, "Did you think that the dissection of a cadaver is ethically acceptable?" it was determined that this question was $80 \%$ yes, $8 \%$ no, $13 \%$ were unstable( 12$)$.

In the Tschernig et al study it was mentioned that educators should have ethical sensitivity in particular. In addition, there were no significant differences between female and male students or between "younger" and "older" students about dissection course (13).

Bob et al have addressed ethical issues within a general framework in their research. More physical and emotional problems came to the forefront. A small percentage of them may have feelings of horror, apprehension, guilt, wonder, gratitude, sadness and even overwhelming physical reactions, nightmares, intrusive visual images, insomnia, depression, and learning impairments(14).

Shaikh wrote in a review the ethical concerns in the dissection of cadavers "Anatomical dissection is a time honoured part of medical education". However, the use of human tissues for research purposes, the use of human cadavers for teaching and training purposes is surrounded by ethical uncertainties. The main ethical concern of cadaver dissection lies in respect to human life(10).

In Kennedy's book; a particular act of an acceptable type of action involving the tissue removal may be wrong if the person from whom the tissue is removed does not consent since its removal without consent in these conditions would constitute impermissible injury. For example, use of some persons as organ banks for others without their knowledge or consent, or the removal of a person's tissue for experimental purposes without his or her consent, or body snatching for medical research would all be seen as ethically impermissible. The ethical failing here is not that every use of organs, tissue or cadavers is unacceptable, but that these particular ways of procuring them violate consent considerations(15).

\section{Physical and emotional reactions detected}

The commonest symptoms experienced were a loss of appetite. The commonest cause of their symptoms was studied and the result shows that it was the smell of the dissection $\operatorname{room}(5)$.

Most students experienced negative physical symptoms, such as eye soreness, mile headache or dizziness, a decrease in appetite, nausea, and disgust, in the first encounter with a cadaver in the dissection room. They also experienced adverse emotional responses, such as surprise, depression, sadness, fear and feelings of guilt, anxiety, and crying(16).

The review of anxiety reveals the circumstances such as exhaustion, stress, depression, anxiety, destructive life, deterioration of mental or physical quality or over-fatigue, professionally having a serious effect on the students(2).

Negative effects were significantly more frequently reported by women and students in clinical training. The predominant factor in the various coping strategies for dissection practicals is cognitive coping (rationalisation, intellectualisation). Physical and emotional coping strategies followed, with similar mean scores(17).

First-year medical students report a positive response to their initial experience with a cadaver in the anatomical dissection room. In the case of only $13.63 \%$ of these students, the anatomical dissection room was the most stressing aspect of the anatomy syllabus(18).

Majority of the students found their first visit to the dissection room exciting. A third of the respondents felt emotional shock at initial exposure to the cadaver(19).

Some students showed an initial sense of concern, worry, or uneasiness as they entered the cadaver lab and began the dissection(20).

For some students dissection was emotional stress; about $50 \%$ became anxious when coping 
with the first confrontation(21).

Five percent of students were very upset by the dissection room during the first few sessions while $36 \%$ were slightly upset, and $58 \%$ were unaffected $(22)$.

The most frequent reactions were recurring visual images of cadavers and temporary loss of appetite. The students' reactions were most commonly elicited by the smell of the dissection room and the fear of infection(23).

A third of the students identified the dissection room as a "very important" stressor. Only for female respondents were "dissecting room" and "great difficulty of work" significantly associated as causes of stress (24).

Ethnicity and previous exposure to dying have no effect on responses, but overall the male students' reactions were significantly less(25).

A total of $71.8 \%$ of the students reported no fear when they entered the dissection room while $28.2 \%$ experienced a varying degree of fear(26).

\section{Discussion}

The following have not been found in publications that we have investigated for titles that may cause an ethical problem. For example; lack of approval for being a cadaver in life, being a student who thinks that a cadaver is a human being and should not be touched to harm it, the presence of a student in the opposite sex who does not want to examine her due to the gender of the cadaver, the student's rejection of this course, trying to make a selfie with a cadaver, have fun with a cadaver, damage to the cadaver unnecessarily, forgetting that once the cadaver was a human being disrespectful behaviors are exhibited by students and educators, etc. In publications dealing with the issue of ethics, it is seen that the detailed mentioned problems are not addressed.

A question in the study of Agnihotri and Sagoo from the research publications we investigated the ethical acceptability of the cadaveric dissection, and a similar question was also investigated in the Rajeh et al. $(11,12)$.
In a research work, Tschernig et al emphasized the importance of the anatomists' awareness of ethical problems (13).

The physical and emotional problems relating to the cadaver lessons in most of the publications came to the forefront. Some of these issues are: The results show that initial encounters with a cadaver in the dissecting room caused emotional and physical distress to first-year medical students. Before the students' applied lessons with the cadavers start, a preparatory session must be planned for this education to decrease the anxiety level by sharing their sensations, feelings, and perceptions relating to the demonstration. After the first week of dissection, most of the students found the experience challenging, stimulating, exciting and informative, rather than nauseating or unbearable. Still, some students found the experience anxiety-provoking, especially when they thought about human mortality. The anatomists, most be the firsts to be aware of emotional and ethical issues, need to explain in detail the steps necessary for dissection and that dissection is performed with the respect of legislation, ethics and human rights $(2,14,16,27)$.

In particular, some of the publications mentioned emotional issues: Emotions evoked are often heightened by the fear and uneasiness each student experiences when dissecting the body of a human being. The barriers to dissection are mainly logistic and psychological; an issue that can be solved through proper strategic organizational planning and an improved access to scientifically oriented information in order to rule out emotional bia$\operatorname{ses}(1,28-30)$.

The present study findings show that the smell of the dissection room, touch, and fear of cadaver were the commonest cause of the symptoms experienced for the majority of students. Thus, instructors should give awareness-raising education to the students before the commencement of the dissection session, students should be mentally and emotionally ready to do their work enthusiastically and confidently. A similar approach has been found in Mulu and Tegabu study: Instructors are recommended to adequately prepare students mentally and emotionally before the commencement of the dissection session for an 
exciting and stress-free anatomy learning through dissection. In addition: The initiation ceremony, which showed a body donor's deeds and attitudes toward life and death when they were alive, could help medical students gain more mature attitudes towards death and decreased negative emotions $(5,31,32)$.

In general, the majority of students were coping well by accepting the fact that dissection is happening and seeing the good in what is being done. Half of them were trying to see dissection in a different light to make it seem more positive, and some were getting emotional support from others and getting help and advice from other people. About half of them simply learned to live with it(27).

The studies provide an insight on the perception of dissection, and the symptomatic and emotional reactions students experienced in dissection hall in the local settings of a medical faculty. The results indicate that medical students do not report their first exposure to cadaver dissection as an aversive experience. When asked about their experiences during dissection, the majority of students stated that it was essential for learning anatomy (33-35).

\section{Conclusion}

It has been determined that students have experienced in the cadaver lessons some physical and emotional problems in the publications. In our research, quite a few publications have been found that dealt with ethical problems in cadaver lessons. The ethical considerations in these publications are not exhaustive.

The introduction of ethical problems in cadaver lessons with detailed studies will contribute to the education of medical faculty students.

Acknowledgments: I would like to thank the authors of the publications reviewed in this research.

\section{Financial support and sponsorship: Nil.}

Conflicts of interest: There are no conflicts of interest.

\section{References}

1. Hasan T. Is dissection humane? J Med Ethics Hist Med. 2011; 4: 4.

2. Bati AH, Ozer MA, Govsa F, Pinar Y. Anxiety of first cadaver demonstration in medical, dentistry and pharmacy faculty students. Surg Radiol Anat. 2013; 35: 419-426.

3. Egwu OA, Ugwu AC, Eteudo AN, Ewunonu EO, Njoku CO. Perceptions of medical students undergoing cadaveric training: a sociocognitive perspective. Internet Journal of Medical Update 2008; 3(2): 8-12.

4. Weeks SE, Harris EE, Kinzey WG. Human Gross Anatomy: A Crucial Time to Encourage Respect and Compassion in Students. Clinical Anatomy 1995; 8: 69-79.

5. Getachew D. Reaction of Medical Students to Experiences in Dissection Room. Ethiop J Health Sci. 2014; $24(4): 337-$ 342.

6. Aydın I. Ethics in Education and Instruction. Second ed. Ankara. Pegem publishing 2006; 13-30.

7. Kadıglu F, Kadıoglu S. Ethical Decision Making Process in Clinical Practice. Erdemir Demirhan A, Oguz Y, Elcioglu O, Dogan H. Eds. Clinic Ethics. Nobel Publishing; 2001: 44-63.

8. Yıldırım G, Kadıoglu S. Basic Concepts of Ethics and Medical Ethics. C.U. Faculty of Medicine Journal 2007; 29(2) $: 7-12$.

9. Beauchamp TL, Childress JF. Principles of Biomedical Ethics. Third ed. Oxford University Press; 1989.

10. Shaikh ST. Cadaver Dissection in Anatomy: The Ethical Aspect. Anat Physiol. 2015; 5: S5.

11. Agnihotri G, Sagoo MG. Reactions of first year Indian medical students to the dissection hall experience. NJIRM 2010; 1(4) :4-9.

12. Rajeh NA, Badroun LE, Alqarni AK, Alzhrani BA, Alallah BS, Almghrabi SA, Almalki LA. Cadaver dissection: A positive experience among Saudi female medical students. Journal of Taibah University Medical Sciences 2017; 12(3): 268-272.

13. Tschernig T, Schlaud M, Pabst R. Emotional reactions of medical students to dissecting human bodies: A conceptual approach and its evaluation. The Anatomical Record 2000; 261(1): 11-13. 
14. Bob MH, Popescu CA, Armean MS, Suciu SM, Buzoianu AD. Ethical views, attitudes and reactions of Romanian medical students to the dissecting room. Rev. Med. Chir. Soc. Med. Nat., Iaşi. 2014; 118(4): 1078-1085.

15. Kennedy I. Ethical principles: respect for human lives and the human body. Nairne P, edit. In Human Tissue Ethical and Legal Issues. London: Nuffield Council on Bioethics; 1995: 39-54.

16. Lee YH, Lee YM, Kwon S, Park SH. Medical students' reactions to anatomic dissection and the phenomenon of cadaver naming. Korean J Med Educ. 2011; 23(4): 275-283.

17. Sándor I, Birkás E, Győrffy Z. The effects of dissection-room experiences and related coping strategies among Hungarian medical students. BMC Medical Education 2015; 15(73): 1-9.

18. Romero RR. Anatomical Dissection: A Positive Experience for Venezuelan First Year Medical Students. Int. J. Morphol. 2010; 28(1): 213-217.

19. Karau PB, Wamachi A, Ndede K, et al. Perception to cadaver dissection and views on anatomy as a subject between two pioneer cohorts in a kenyan medical school. Anatomy Journal of Africa 2014; 3(2): 318-323.

20. Fortunato J, Wasserman J, Hankin M. Students' Understandings of their Ethical Obligations to their Cadavers after their First Anatomy Lab: A Qualitative Study. FASEB Journal. This abstract is from the Experimental Biology Meeting; 2016.

21. Bernhardt V, Rothkötter HJ, Kasten E. Psychological Stress In First Year Medical Students In Response To The Dissection of Human Corpse. GMS Z Med Ausbild. 2012; 29(1): 1-17.

22. Evans EJ, Fitzgibbon GH. The dissecting room: Reactions of first year medical students. Clinical Anatomy 1992; 5(4): 311-320.

23. Abu-Hijleh MF, Hamdi NA, Moqattash ST, Harris PF, Heseltine GFD. Attitudes and reactions of Arab medical students to the dissecting room. Clinical Anatomy 1997; 10(4): 272-278.

24. Nnodim JO. Preclinical student reactions to dissection, death, and dying. Clinical Anatomy 1996; 9(3): 175-182.

25. Charlton R, Dovey SM, Jones DG, A. Blunt A. Effects of cadaver dissection on the attitudes of medical students. Medical Education 1994; 28(4): 290-295.

26. Bataineh ZM, Hijazi TA, Abu Hijleh MF. Attitudes and reactions of Jordanian medical students to the dissecting room. Surgical and Radiologic Anatomy 2006; 28: 416.

27. Hussein IH, Dany M, Forbes W, Barremkala M, Thompson BJ, Jurjus A. Perceptions of human cadaver dissection by medical students: a highly valued experience. IJAE 2015; 120(3): 162-171.

28. Bertman SL, Marks SC Jr. Humanities in medical education: rationale and resources for the dissection laboratory. Med Educ. 1985; 19(5):374-381.

29. Horne DJ, Tiller JW, Eizenberg N, Tashevska M, Biddle N. Reactions of first-year medical students to their initial encounter with a cadaver in the dissecting room. Acad Med. 1990; 65(10): 645-646.

30. Williams AD, Greenwald EE, Soricelli RL, DePace DM. Medical Students' Reactions to Anatomic Dissection and the Phenomenon of Cadaver Naming. Anat Sci Educ. 2014; 7(3): 169-180.

31. Chiou RJ, Tsai PF, Han DY. Effects of a "silent mentor" initiation ceremony and dissection on medical students' humanity and learning. BMC Res Notes 2017; 10: 483.

32. Mulu A, Tegabu D. Medical Students' Attitudinal Changes Towards Cadaver Dissection: A Longitudinal Study. Ethiop J Health Sci. Ethiop J Health Sci. 2012; 22(1): 51-58.

33. Lempp HK. Perceptions of dissection by students in one medical school: beyond learning about anatomy. A qualitative study. Medical Education 2005; 39: 318-325.

34. O'carroll RE, Whiten S, Jackson D, Sinclair DW. Assessing the emotional impact of cadaver dissection on medical students. Medical Education 2002; 36(6): 550-554.

35. Qamar K, Osama M. Role of dissection in light of students' perceptions. JPMA 2014; 64: 102110-24.

Received: March 22, 2018

Accepted: June 26, 2018 